\title{
BIOSECURITY IMPLICATIONS OF EXOTIC BEETLES ATTACKING TREES AND SHRUBS IN NEW ZEALAND
}

\author{
E. G. BROCKERHOFF ${ }^{1,3}$ and J. BAIN ${ }^{2}$ \\ ${ }^{1}$ Forest Research, PO Box 29237, Christchurch \\ ${ }^{2}$ Forest Research, Private Bag 3020, Rotorua \\ ${ }^{3}$ Author for correspondence
}

\begin{abstract}
A survey of exotic beetles that attack trees or shrubs in New Zealand found 51 species of mainly Australian (58\%) and European $(25 \%)$ origin. In addition, three biological control agents have been released against woody adventive plant pests. The host range of most species is restricted to exotic crop and ornamental plants in New Zealand. Nine polyphagous borers sometimes attack dead wood of indigenous species, and at least one polyphagous root feeder may attack indigenous trees, but the ecological impact of these species on indigenous forests appears negligible. However, some of the wood and bark borers as well as several defoliators are important pests of exotic crop and amenity plants. Although this suggests that exotic phytophagous beetles pose a greater biosecurity threat to exotics than to indigenous species, a greater surveillance effort in New Zealand's indigenous forests appears necessary to detect potentially harmful invasions.
\end{abstract}

Keywords: invasion, Coleoptera, host range, insect, tree.

\section{INTRODUCTION}

The colonisation of New Zealand by Polynesians and Europeans has led to the accidental or intentional introduction of numerous exotic plants and animals. Today there are over 2000 plant, nearly 100 vertebrate and over 2000 invertebrate species that are naturalised exotics (Atkinson and Cameron 1993; Ministry for the Environment 1997). The impact of invasive plant pests and mammalian herbivores and predators on New Zealand's ecosystems is well recognised (Atkinson and Cameron 1993). Many indigenous species have not been able to compete with the colonisers because the New Zealand fauna and flora evolved during the last 80 million years in geographic isolation and in the almost complete absence of mammals. Evidence of this is the loss or decline of numerous species during the last few centuries (Ministry for the Environment 1997), although the loss of habitat, hunting, and other human-caused disturbances have also contributed. Among the insects that have invaded New Zealand's indigenous habitats, the common wasp, Vespula vulgaris (L.) (Hymenoptera: Vespidae), has been particularly successful, and represents a well-documented, significant threat to indigenous invertebrates (Beggs and Rees 1999) and birds (Beggs and Wilson 1991). There are also a number of important insect pests of trees that have become established (Scott 1984; Charles 1998) or are being regularly intercepted at the border (Bain 1977; Keall 1981; Ridley et al. 2000). However, it appears that these species primarily attack exotic trees, and that very few of them pose a significant threat to indigenous forests (Ridley et al. 2000). Elsewhere, for example in North American forests, the effects of introduced forest insects have been dramatic and the subject of much research (Liebhold et al. 1995; Niemelä and Mattson 1996; Wallner 1996). During the last century, the European gypsy moth, Lymantria dispar L. (Lepidoptera: Lymantriidae), regularly defoliated millions of hectares of indigenous North American oak forests, which resulted in considerable tree mortality and significant changes in tree species composition of forests (Gottschalk 1990). Instances where introduced pest species have changed the composition of indigenous forests have been discussed

New Zealand Plant Protection 53:321-327 (2000) 
by Smith (1976). Until recently there was no general information on the impact of established exotic phytophagous insects on New Zealand's indigenous forests (Ridley et al. 2000).

We are conducting a detailed review of the origin and host range of exotic insects that attack trees and shrubs in New Zealand to increase our understanding of the ecology of herbivorous insect invasions and to determine the potential threat from these species to our indigenous and exotic forests. This article presents the initial results for exotic beetles (Coleoptera) that feed on trees or shrubs.

\section{MATERIALS AND METHODS}

Data on exotic beetles attacking trees or shrubs, as well as host plant records were compiled from (i) the Forest Health database maintained by Forest Research, Rotorua, (ii) specimen labels in the National Forest Insect Collection (FRNZ) at Forest Research and (iii) unpublished records of exotic forest pests (J. Bain, unpublished manuscript; R. Zondag, unpublished manuscript). Additional data on established insects and their host plants were obtained from Spiller and Wise (1982), Kuschel (1990) and relevant publications cited therein and in Klimaszewski and Watt (1997). We also consulted several New Zealand entomologists with expertise in this area to verify the completeness of our data. Unfortunately, we were unable to obtain data from the MAF Plant Pest Information Network (PPIN) which maintains a substantial data base on plant pests and their host associations. However, PPIN data cover primarily the agricultural sector and would probably not contribute much additional information about forest pests.

Because of New Zealand's reliance on exotic crop plants, including forestry and ornamental tree and shrub species, plant protection research has tended to focus on exotic rather than indigenous plants (Ridley et al. 2000). This could have led to a bias in our data, such that attacks on indigenous plants would be under-represented. However, this potential bias is unlikely to affect the overall results of the study because significant attacks on indigenous plants would probably have been noticed anyway.

\section{RESULTS AND DISCUSSION}

There are at least 356 exotic beetle species established in New Zealand (Klimaszewski and Watt 1997). Our survey of beetles that attack parts of trees or shrubs revealed 51 accidentally introduced species and three additional species that have been released as weed biocontrol agents against exotic woody plant pests (Table 1). The latter have been excluded from the analysis because they were intentionally released, and they were subjected to comprehensive host specificity tests prior to release so that attacks on non-target plants would be unexpected. Among the accidental introductions, 12 beetle families are represented, with Curculionidae (24 species, including 10 Scolytinae), Cerambycidae (9 species) and Chrysomelidae (6 species) contributing the most species (Table 1). When classified by feeding guild, wood borers are the largest group, followed by root feeders, bark borers and defoliators (Table 1). This suggests that wood and bark-boring beetles pose a higher invasion risk than external feeders such as defoliators, presumably because the former are easily imported in infested wood products and packaging. However, recent invasion trends (1988-1997) assessing all insect orders show that defoliators and sapsuckers predominate among the species attacking trees or shrubs (Ridley et al. 2000). Most introduced beetles are from Australia representing about $58 \%$ of the species of known origin, followed by European species (Fig. 1). Thus, it appears that the origin of these exotic beetles reflects the proximity of Australia as well as Australian and European trade relations which traditionally predominated. This could be explained by the resulting high 'propagule pressure' from these areas, which is generally assumed to be one of the correlates of invasion success (Williamson 1996).

The majority of host records for exotic beetles are from exotic plants. The complete list of exotic host plants for all species is beyond the scope of this paper but can be obtained from the authors. There are substantially fewer records of attacks on indigenous trees or shrubs than on exotics, and with few exceptions these species 


\section{TABLE 1: Exotic beetles attacking trees or shrubs in New Zealand: the year of their first record in New Zealand and their region of origin.}

Feeding guild, Species (Family ${ }^{1}$, Year, Origin ${ }^{2}$ )

Root feeders

Asynonychus (=Pantomorus) cervinus (Boheman) ${ }^{3}$ (Curculionidae, 1937, S.Am.);

Graphognathus leucoloma (Boheman) (Curculionidae, 1944, S.Am.); Otiorhychus ovatus

(L.) (Curculionidae, 1936, Eur.); Otiorhynchus rugosostriatus (Goeze) (Curculionidae,

1940, Eur.); Otiorhynchus sulcatus (F.) (Curculionidae, 1866, Eur.); Phlyctinus callosus

Boheman (Curculionidae, 1893, S.Afr.); Steriphus diversipes lineata (Pascoe)

(Curculionidae, 1925, Aus.); Heteronychus arator (F.) (Scarabaeidae, 1937, S.Afr.)

Bark borers

Cryphalus wapleri Eichhoff (Scolytinae, 1946, Aus.); Hylastes ater (Paykull) (Scolytinae, 1929, Eur.); Hylurgus ligniperda (F.) (Scolytinae, 1974, Eur.); Phloeosinus cupressi Hopkins (Scolytinae, 1926, N.Am.); Scolytus multistriatus Marsham (Scolytinae, 1989, Eur.)

Wood borers

Anobium punctatum de Geer (Anobiidae, 1875, Eur.); Deroptilinus granicollis Lea (Anobiidae, 1969, Aus.); Ernobius mollis L. (Anobiidae, 1930, Eur.); Hadrobregmus australiensis Pic (Anobiidae, 1937, Aus.); Lyctus brunneus (Stephens) (Bostrichidae, 1903, N.Am.); Arhopalus tristis (Mulsant) (Cerambycidae, 1963, Eur.); Aridaeus thoracicus (Donovan) (Cerambycidae, 1954, Aus.); Bethelium signiferum (Newman) (Cerambycidae, 1840, Aus.); Callidiopsis scutellaris (F.) (Cerambycidae, 1935, Aus.); Coptocercus rubripes (Boisduval) (Cerambycidae, 1931, Aus.); Didymocantha obliqua Newman (Cerambycidae, 1960, Aus.); Nathrius brevipennis (Mulsant) (Cerambycidae, 1993, Eur.); Phoracantha semipunctata (F.) ${ }^{4}$ (Cerambycidae, 1873, Aus.); Tessaromma undatum Newman (Cerambycidae, 1902, Aus.); Dryophthorus sp. ${ }^{5}$ (Curculionidae, 1975, unknown); Mesites pallidipennis Boheman (Curculionidae, 1958, Eur.); Neolaemosaccus narinus (Pascoe) (Curculionidae, 1939, Aus.); Pselactus spadix (Herbst) (Curculionidae, 1886, Eur.); Stenoscelis hylastoides Wollaston (Curculionidae, 1941, S.Afr.); Agrypnus variabilis (Candèze) (Elateridae, 1870, ?); Rhyssonotus nebulosus (Kirby) (Lucanidae, 1950, Aus.); Syndesus cornutus (F.) (Lucanidae, 1961, Aus.); Mordellistena sp. (Mordellidae, 1981, ?); Amasa truncatus (Erichson) (Scolytinae, 1930, Aus.); Ambrosiodmus compressus (Lea) (Scolytinae, 1972, Aus.); Coptodryas eucalyptica (Schedl) (Scolytinae, 1975, Aus.); Xyleborinus saxeseni (Ratzeburg) (Scolytinae, 1963, Eur.); Xylosandrus solidus (Eichhoff) (Scolytinae, 1978, Aus.); Amarygmus sp. (A. tristis sensu Blackburn) (Tenebrionidae, 1956, Aus.)

Defoliators

Dicranosterna semipunctata (Chapuis) (Chrysomelidae, 1996, Aus.); Ocrosopsis subfasciata (Saunders) (Chrysomelidae, 1980, Aus.); Paropsis charybdis Stal (Chrysomelidae, 1916, Aus.); Pyrgoides sp. ${ }^{6}$ (Chrysomelidae, 1976, Aus.); Trachymela catenata (Chapuis) (Chrysomelidae, 1992, Aus.); Trachymela sloanei (Blackburn) (Chrysomelidae, 1976, Aus.); Gonipterus scutellatus Gyllenhal (Curculionidae, 1890, Aus.)

Seed feeders

Araecerus palmaris (Pascoe) (Anthribidae, 1894, Aus.); Storeus albosignatus Blackburn (Curculionidae, 1939, Aus.)

Biological control agents

Apion ulicis (Forster) (Apionidae, 1931, Eur., seed feeder on Ulex europaeus); Bruchidius villosus F. (Chrysomelidae (Bruchidae), 1987, Eur., seed feeder on Cytisus scoparius); Lochmaea suturalis Thomson (Chrysomelidae, 1996, Eur. , defoliator of Calluna vulgaris)

\footnotetext{
${ }^{1}$ Scolytidae have recently been included with Curculionidae as the subfamily Scolytinae. To distinguish this taxon from the conventionally separate Curculionidae, we list them here as 'Scolytinae'.

${ }^{2}$ Aus., Australia; Eur., Europe; N.Am., North America; S.Afr., Southern Africa; S.Am., South America; ?, unknown.

${ }^{3}$ Larvae of A. cervinus are root feeders, adults are defoliators.

${ }^{4}$ Phoracantha semipunctata has incorrectly been recorded as Phoracantha recurva Newm. (Clark 1938; Spiller and Wise 1982).

${ }^{5}$ This is an undescribed species (May 1993).

${ }^{6}$ This species has only been recorded by Kuschel (1990) and is possibly not established.
} 


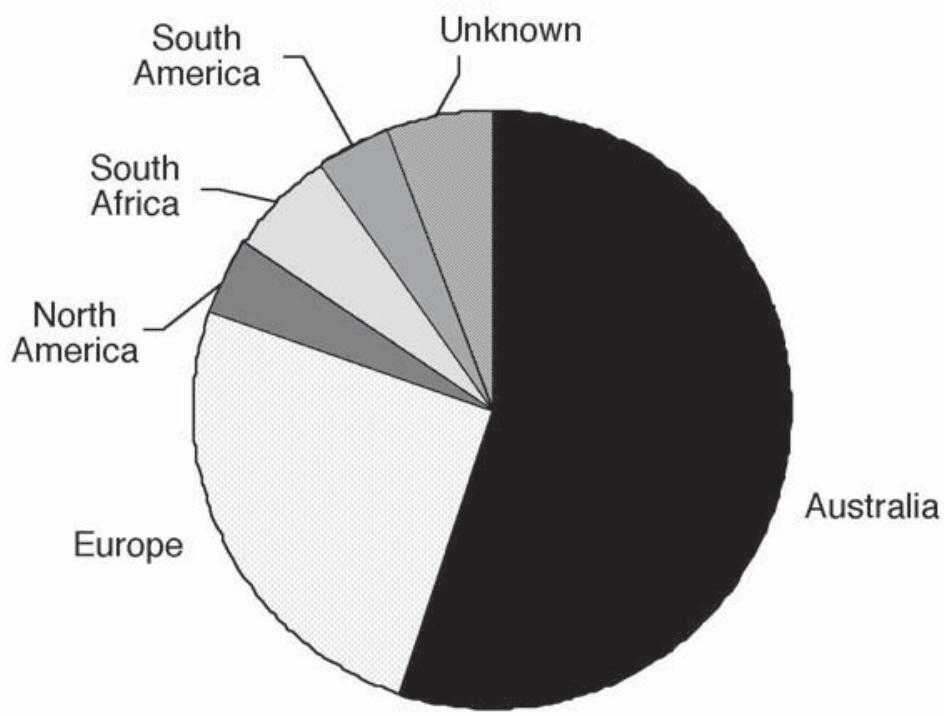

FIGURE 1: Origin of exotic beetles attacking trees or shrubs in New Zealand, excluding agents introduced for the biological control of weeds.

attack dead or rotting wood (Table 2). In addition, there are several records of rootfeeding species which are generally less host specific, but only for the weevil Asynonychus cervinus has attack on indigenous trees been recorded (Table 2). Several Otiorhynchus species and Phlyctinus callosus (Table 2) probably also attack indigenous trees or shrubs. These weevils are highly polyphagous root feeders that have been recorded from a wide variety of plant taxa, including several exotic trees and shrubs. However, none of the dead-wood borers or root feeders are known to have a significant ecological impact on indigenous plants. Despite this, several of the wood borers have become notable pests in economic terms. For instance, the house borer, Anobium punctatum (Table 1), is a serious pest of exotic and indigenous structural timber (Table 2) in residential dwellings (Hosking 1978). A number of other wood and bark boring species also rank highly as quarantine pests, and their presence in export timber frequently requires fumigation of such material (Brockerhoff and Hosking, in press).

The apparent lack of attack on indigenous trees and shrubs by exotic Coleoptera indicated by our data was unexpected since some of our exotic beetles are considered serious pests in New Zealand. For example, Paropsis charybdis and Dicranosterna semipunctata (Table 1) are known to severely defoliate Eucalyptus spp. and Acacia spp., respectively, in New Zealand. Repeated defoliation by these species can cause tree mortality (Bain and Kay 1989). The elm bark beetle, Scolytus multistriatus (Table 1), poses a significant threat to elms, Ulmus spp., because it is one of the vectors of the fungal pathogens, Ophiostoma ulmi and O. novo-ulmi, which cause the fatal Dutch elm disease (Gadgil et al. 2000). These and other highly host-specific beetle species only attack their natural host plants which are exotic trees and shrubs. The host range of each of these beetle species usually consists of a few taxonomically close plant species that have no near relatives among New Zealand's indigenous flora. Thus, our indigenous tree and shrub flora, with its many endemic species, appears not to be at a great risk from exotic beetles. A preliminary analysis of the impact of insects on New Zealand's forests suggests these results also apply to other insect taxa (Ridley et al. 2000). Conversely, North American forests are threatened by Eurasian insects because these continents share many plant genera (Niemelä and Mattson 1996). These 


\section{TABLE 2: Exotic beetles that have been recorded feeding on indigenous trees or shrubs in New Zealand, and their host range.}

\begin{tabular}{|c|c|c|c|}
\hline $\begin{array}{l}\text { Species } \\
\text { and family } \\
\text { or subfamily }\end{array}$ & $\begin{array}{l}\text { Host } \\
\text { range } \\
\text { summary }\end{array}$ & $\begin{array}{l}\text { Host species (indigenous } \\
\text { species are underlined, for exotic } \\
\text { species, only genera are listed) }\end{array}$ & Source $^{1}$ \\
\hline $\begin{array}{l}\text { Anobium punctatum } \\
\text { (Anobiidae) }\end{array}$ & $\begin{array}{l}\text { polyphagous wood } \\
\text { borer of dead exotics } \\
\text { and natives }\end{array}$ & $\begin{array}{l}\text { Dacrycarpus dacrydioides, Dacrydium } \\
\text { cupressinum, Crataegus, Cupressus, } \\
\text { Cytisus, Eucalyptus, Pinus, Populus, } \\
\text { Pseudotsuga, Salix, Sequoiadendron }\end{array}$ & 1,2 \\
\hline $\begin{array}{l}\text { Hadrobregmus } \\
\text { australiensis } \\
\text { (Anobiidae) }\end{array}$ & $\begin{array}{l}\text { polyphagous wood } \\
\text { borer of dead exotics } \\
\text { and natives }\end{array}$ & $\begin{array}{l}\text { Metrosideros excelsa, Leucopogon } \\
\text { fasciculatus, plywood, Cupressus, } \\
\text { Acacia, Pinus }\end{array}$ & 3 \\
\hline $\begin{array}{l}\text { Aridaeus thoracicus } \\
\text { (Cerambycidae) }\end{array}$ & $\begin{array}{l}\text { oligophagous wood } \\
\text { borer of a dead native }\end{array}$ & Avicennia marina ssp. australasica & 2 \\
\hline $\begin{array}{l}\text { Mesites pallidipennis } \\
\text { (Curculionidae) }\end{array}$ & $\begin{array}{l}\text { polyphagous wood } \\
\text { borer of dead } \\
\text { exotics and natives }\end{array}$ & $\begin{array}{l}\text { Nothofagus sp., Pinus, } \\
\text { marine driftwood }\end{array}$ & $\begin{array}{l}2,4 \\
5,6\end{array}$ \\
\hline $\begin{array}{l}\text { Lyctus brunneus } \\
\text { (Bostrichidae) }\end{array}$ & $\begin{array}{l}\text { polyphagous wood } \\
\text { borer of dead } \\
\text { exotics and natives }\end{array}$ & $\begin{array}{l}\text { Beilschmiedia tawa, Knightia excelsa, } \\
\text { Nothofagus spp., Bambusae sp., } \\
\text { Eucalyptus, Fraxinus, Magnolia, } \\
\text { Populus, Quercus, Ulmus }\end{array}$ & 2,7 \\
\hline $\begin{array}{l}\text { Amasa truncatus } \\
\text { (Scolytinae) }\end{array}$ & $\begin{array}{l}\text { polyphagous wood } \\
\text { borer of dead } \\
\text { exotics and natives, } \\
\text { also in live eucalypts }\end{array}$ & $\begin{array}{l}\text { Broods found in Kunzea ericoides, } \\
\text { Leptospermum scoparium, Knightia } \\
\text { excelsa, Metrosideros robusta, } \\
\text { Metrosideros excelsa, Weinmannia } \\
\text { racemosa, Acacia, Albizia, Eucalyptus. } \\
\text { Adults found boring in most of the } \\
\text { above spp., also in Prumnopitys } \\
\text { taxifolia, Pinus, Pseudotsuga, Vitex }\end{array}$ & $\begin{array}{l}2,3 \\
8,9\end{array}$ \\
\hline $\begin{array}{l}\text { Ambrosiodmus } \\
\text { compressus } \\
\text { (Scolytinae) }\end{array}$ & $\begin{array}{l}\text { polyphagous wood } \\
\text { borer of dead or } \\
\text { dying exotics } \\
\text { and natives }\end{array}$ & $\begin{array}{l}\text { Broods found in Acacia, } \\
\text { Chamaecytisus, Eucalyptus, Pinus, } \\
\text { Prunus. Adults found boring in } \\
\text { Coriaria arborea, Kunzea ericoides, } \\
\text { Melicytus ramiflorus, Acacia, Pinus, } \\
\text { Pseudotsuga }\end{array}$ & $2,9,10$ \\
\hline $\begin{array}{l}\text { Coptodryas } \\
\text { eucalyptica } \\
\text { (Scolytinae) }\end{array}$ & $\begin{array}{l}\text { polyphagous wood } \\
\text { borer of dead or } \\
\text { dying exotics } \\
\text { and natives }\end{array}$ & $\begin{array}{l}\text { Melicytus ramiflorus, Corynocarpus } \\
\text { laevigatus, Ulmus, Acacia, Ligustrum }\end{array}$ & 2,10 \\
\hline $\begin{array}{l}\text { Amarygmus sp. } \\
\text { (A. tristis sensu } \\
\text { Blackburn) } \\
\text { (Tenebrionidae) }\end{array}$ & $\begin{array}{l}\text { polyphagous borer } \\
\text { in decaying tree } \\
\text { stumps of exotics } \\
\text { and natives }\end{array}$ & $\begin{array}{l}\text { Avicennia marina ssp. australasica, } \\
\text { Eucalyptus, Pinus }\end{array}$ & 2,11 \\
\hline $\begin{array}{l}\text { Asynonychus } \\
\text { cervinus } \\
\text { (Curculionidae) }\end{array}$ & $\begin{array}{l}\text { polyphagous root } \\
\text { feeder (larvae) of } \\
\text { exotics and natives; } \\
\text { defoliator (adults) } \\
\text { of exotics }\end{array}$ & $\begin{array}{l}\text { Larvae on roots of Corynocarpus } \\
\text { laevigatus, Entelea arborescens, } \\
\text { Acacia, Actinidia, Cirsium, Citrus, } \\
\text { Clematis, Cytisus, Fuchsia, Pinus, } \\
\text { Rosa, Solanum, Talauma, Vinca. } \\
\text { Adults defoliate Citrus }\end{array}$ & $\begin{array}{l}2,4,5 \\
12,13\end{array}$ \\
\hline $\begin{array}{l}\text { Otiorhychus ovatus, } \\
\text { O. rugosostriatus, } \\
\text { O. sulcatus, } \\
\text { Phlyctinus callosus } \\
\text { (Curculionidae) }\end{array}$ & $\begin{array}{l}\text { polyphagous root } \\
\text { feeders of exotics, } \\
\text { probably also } \\
\text { of natives }\end{array}$ & $\begin{array}{l}\text { On live roots of numerous species, } \\
\text { including some shrub and } \\
\text { tree species }\end{array}$ & $\begin{array}{l}2,4,5 \\
6,12\end{array}$ \\
\hline
\end{tabular}

\footnotetext{
${ }^{1}$ Sources are as follows: 1, Hosking (1978); 2, Forest Research, Forest Health Database; 3, Kuschel (1990); 4, May (1987); 5, May (1993); 6, Kuschel (1972); 7, Bain (1978); 8, Zondag (1977); 9, R. Zondag, unpubl. data; 10, E.G. Brockerhoff, unpubl. data; 11, Watt (1992); 12, Spiller and Wise (1982); 13, Scott (1984).
} 
invasion patterns are consistent with the fact that most phytophagous insects are at least moderately host specific (Jaenicke 1990). Thus, the large impact European or Asian insect pests have had in North America (Liebhold et al. 1995; Niemelä and Mattson 1996) may not be expected in New Zealand's indigenous forests. Rather, insect pests from regions with a flora more similar to that of New Zealand, such as Tasmania and Chile, would probably pose a greater threat to New Zealand's forests (see Ridley et al. 2000). Nevertheless, some polyphagous Northern Hemisphere insects, such as gypsy moth, might well create havoc in our indigenous forests should they become established.

Exotic crops planted in New Zealand are at a greater biosecurity risk. Our examination showed that among the established beetle species, 21 are primarily associated with the Australian genera Eucalyptus, Acacia and Ficus, and eight are associated with Pinus, Cupressus, Salix, Ulmus and related genera. This suggests that the presence of many exotic plant genera, primarily from Australia and the Northern Hemisphere, greatly facilitates the invasion by beetle species associated with plants from these regions. Such exotic trees are likely to be under continued pressure from an ever increasing number of introduced pests despite our biosecurity efforts. However, to detect potential biosecurity threats it is not only essential to maintain vigilant border control and port environs surveillance, but also to monitor our indigenous forests. Because of our reliance on exotic crop species, including forest trees, the surveillance of indigenous forest trees and shrubs for insect pests is currently limited (Ridley et al. 2000) and new insect pests might go unnoticed for some time. This is exacerbated by our limited knowledge of indigenous insects. Even for beetles, only about 5,000 of the estimated 10,000 species in New Zealand (Kuschel 1990) have been described. Nevertheless, in most cases it should be possible to determine whether a new forest insect pest is indigenous or exotic.

\section{ACKNOWLEDGMENTS}

We thank Willy Kuschel for verification of our data base and provision of unpublished data; Barbara Barratt, Lisa Langer, Alan Leckie, Geoff Ridley and Sue Zydenbos for comments on the manuscript; the NZ Foundation for Research, Science and Technology for funding (CO4807).

\section{REFERENCES}

Atkinson, I.A.E. and Cameron, E.K., 1993. Human influence on the terrestrial biota and biotic communities of New Zealand. TREE 8: 447-451.

Bain, J., 1977. Overseas wood- and bark-boring insects intercepted at New Zealand ports. New Zealand Forest Service, Technical Paper No. 63. 26 pp.

Bain, J., 1978. Lyctus brunneus (Stephens) (Coleoptera: Lyctidae), a powder-post beetle. Forest and Timber Insects in New Zealand 33. Forest Research Institute, Rotorua. 8 pp.

Bain, J. and Kay, M.K., 1989. Paropsis charybdis Stål, Eucalyptus tortoise beetle (Coleoptera: Chrysomelidae). Pp 281-287 In: A Review of Biological Control of Invertebrate Pests and Weeds in New Zealand 1874-1987, P.J. Cameron, R.L. Hill, J. Bain and W.P. Thomas (Eds.); CAB International Publishers, Wallingford, Oxon, U.K.

Beggs, J.R., and Rees, J.S., 1999. Restructuring of Lepidoptera communities by introduced Vespula wasps in a New Zealand beech forest. Oecologia 119: 565571.

Beggs, J.R. and Wilson, P.R., 1991. The kaka (Nestor meridionalis), a New Zealand parrot endangered by introduced wasps and mammals. Biol. Conserv. 56: 23-38.

Brockerhoff, E.G. and Hosking, G.P., in press. Arhopalus tristis (F.), burnt pine longhorn. Forest and Timber Insects in New Zealand 27. Forest Research Institute, Rotorua.

Charles, J.G., 1998. The settlement of fruit crop arthropod pests and their natural enemies in New Zealand: an historical guide to the future. Biocontrol News Inform. 19: 47N-58N. 
Clark, A.F., 1938. A survey of the insect pests of eucalypts in New Zealand.N.Z. J. Sci. Tech. 19: 750-761.

Gadgil, P.D., Bulman, L.S., Dick, M.A., and Bain, J., 2000. Dutch elm disease in New Zealand. Pp 189-199 In: The Elms: Breeding, Conservation, and Disease Management, C.P. Dunn (Ed.); Kluwer Academic Publishers, Boston.

Gottschalk, K.W., 1990. Economic evaluation of gypsy moth damage in the United States of America. Pp 235-246 In: Proceedings XIX World Forestry Congress, Volume 4; IUFRO, Montreal, Canada.

Hosking, G.P., 1978. Anobium punctatum (De Geer) (Coleoptera: Anobiidae), house borer. Forest and Timber Insects in New Zealand 32. Forest Research Institute, Rotorua. 8 pp.

Jaenicke, J., 1990. Host specialization in phytophagous insects. Annu. Rev. Ecol. Syst. 21: 243-273.

Keall, J.B., 1981. Interceptions of insects, mites and other animals entering New Zealand 1973-1978. Ministry of Agriculture and Fisheries, Plant Health Diagnostic Station, Levin. 661 pp.

Klimaszewski, J. and Watt, J.C., 1997. Coleoptera: family-group review and keys to identification. Fauna of New Zealand No. 37. Manaaki Whenua Press, Lincoln, Canterbury. 199 pp.

Kuschel, G., 1972. The foreign Curculionoidea established in New Zealand (Insecta: Coleoptera). N.Z. J. Sci. 15: 273-289.

Kuschel, G., 1990. Beetles in a suburban environment: a New Zealand case study. DSIR Plant Protection Report 3. 118 pp.

Liebhold, A.M., MacDonald, W.L., Bergdahl, D., and Mastro, V.C., 1995. Invasion by exotic forest pests: a threat to forest ecosystems. Forest Science 41 Supplement, Monograph 30: 1-49.

May, B.M., 1987. Immature stages of Curculionoidea (Coleoptera): Rearing records 1964-1986. N.Z. Entomol. 9: 44-56.

May, B.M., 1993. Larvae of Curculionoidea (Insecta: Coleoptera): a systematic overview. Fauna of New Zealand No. 28. Manaaki Whenua Press, Lincoln, Canterbury. 226 pp.

Ministry for the Environment, 1997. The state of New Zealand's environment. Ministry for the Environment, GP Publications, Wellington. 654 pp.

Niemelä, P. and Mattson, W.J., 1996. Invasion of North American forests by European phytophagous insects. Legacy of the European crucible? Bioscience 46: 741-753.

Ridley, G.S., Bain, J., Bulman, L.S., Dick, M.A. and Kay, M.K., 2000. Threats to New Zealand's indigenous forests from exotic pathogens and pests. Science for Conservation No. 142. Dept. of Conservation, Wellington. 67 pp.

Scott, R.R. (Ed.), 1984. New Zealand pest and beneficial insects. Lincoln University College of Agriculture, Canterbury, New Zealand. 373 pp.

Smith, D.M., 1976. Changes in eastern forests since 1600 and possible effects. Pp 320 In: Perspectives in Forest Entomology, J.E Anderson and H.K. Kaya (Eds.); Academic Press, New York. 428 pp.

Spiller, D. and Wise, K.A.J., 1982. A catalogue (1860-1960) of New Zealand insects and their host plants. DSIR Bulletin 231, DSIR, Wellington. $260 \mathrm{pp}$.

Wallner, W.E., 1996. Invasive pests ('biological pollutants') and US forests: whose problem, who pays? OEPP/EPPO Bulletin 26: 167-180.

Watt, J.C., 1992. Tenebrionidae (Insecta: Coleoptera): catalogue of types and keys to taxa. Fauna of New Zealand No. 26. Manaaki Whenua Press, Lincoln, Canterbury. $70 \mathrm{pp}$.

Williamson, M., 1996. Biological invasions. Chapman and Hall, London. 244 pp.

Zondag, R., 1977. Xyleborus truncatus Erichson (Coleoptera: Scolytidae). Forest and Timber Insects in New Zealand 21. Forest Research Institute, Rotorua. 4 pp. 